\title{
Penerapan Metode Inkuiri Terbimbing Berbantukan Modul pada Materi Alat Optik Terhadap Peningkatan Hasil Belajar Siswa SMP dalam Ranah Kognitif
}

\author{
Tria Yuliana ${ }^{1}$, Jeffry Handhika ${ }^{2}$, Farida Huriawati ${ }^{3}$ \\ Universitas PGRI Madiun \\ Email: ${ }^{1)}$ triaayuliana@gmail.com, ${ }^{2)}$ Jhandhika@unipma.ac.id, ${ }^{3)}$ Frd2pfisae@gmail.com
}

\begin{abstract}
Abstrak: Penelitian ini bertujuan untuk mengetahui penerapan hasil belajar IPA fisika dengan menggunakan metode inkuiri terbimbing berbantukan modul. Metode penelitian yang digunakan adalah Quasi Eksperiment dengan desain One-Group Pretest-Postest Design . Populasi penelitian ini adalah kelas VIII SMPN 1 Puhpelem, dan sampel yang digunakan yaitu siswa kelas VIII A yang berjumlah 24 siswa. Instrumen yang digunakan yaitu modul dan soal tes pilihan ganda yang telah diuji validitas dan reliabilitasnya. Teknik analisis data yaitu analisis kuantitatif melalui perhitungan $\mathrm{N}$-Gain untuk mengetahui peningkatan hasil belajar siswa dalam ranah kognitif. Berdasarkan hasil penelitian dapat disimpulkan bahwa penerapan metode pembelajaran inkuiri terbimbing dengan berbantukan modul dapat meningkatkan hasil belajar siswa. Hasil belajar yang diteliti yaitu kategori C1 sampai C4. Hasil penelitian menunjukkan bahwa peningkatan hasil belajar tertinggi terdapat pada kategori $\mathrm{C} 2$. Secara keseluruhan hasil belajar diperoleh N-Gain sebesar 0,67 dengan kategori sedang.
\end{abstract}

Kata Kunci: inkuiri terbimbing, modul, hasil belajar, kognitif

\section{Pendahuluan}

Penelitian TIMSS (Trends In Mathematics and Science Study) pada pemetaan bidang literasi sains tahun 2015, Indonesia menempati ranking 45 dari 48 negara dengan skor 397. Tahun 2015 menjawab benar pada ranah knowing sebesar 37\%, applying sebesar 29\% dan reasoning sebesar 26\%. Dari segi ranking Indonesia mengalami penurunan, tetapi dari segi kognitif siswa mampu meningkatkan presentase. Secara umum, siswa Indonesia lemah di semua aspek konten maupun kognitif, namun diagnosa secara mendalam menemukan hal-hal yang sudah dikuasai. Siswa menguasai soal-soal yang bersifat rutin, komputasi sederhana dengan presentase $80 \%$ benar, dan mengukur pengetahuan akan fakta yang berkonteks keseharian dengan presentase menjawab benar sebesar 91\%. Kelemahan siswa yang perlu ditingkatkan yaitu perlunya penguatan pada kemampuan mengintegrasikan informasi, menarik kesimpulan, serta menggeneralisir pengetahuan yang dimiliki ke hal-hal yang lain. Berdasarkan penelitian tersebut, Indonesia mempunyai kualitas pendidikan yang tergolong rendah, dan perlu adanya upaya untuk meningkatkannya.

Fisika merupakan salah satu mata pelajaran yang tergolong dalam Ilmu Pengetahuan Alam (IPA) dan proses belajarnya sangat memerlukan metode dan media pembelajaran yang tepat. Banyak anggapan dari siswa bahwa fisika itu sulit, tidak menyenangkan dan menakutkan, seperti teori dan persamaan yang susah untuk dihafal. Hal tersebut dikarenakan siswa mengalami kesulitan dalam belajar.

Berdasarkan hasil analisis siswa kelas VIII semester genap tahun ajaran 2016/2017 di SMPN 1 Puhpelem, terdapat beberapa kesulitan siswa yang disebabkan oleh beberapa hal: pertama, siswa kurang mampu memahami konsep-konsep yang dipelajari dikarenakan guru sering menggunakan metode ceramah. Guru menggunakan metode praktikum hanya sekali dalam satu semester, hal tersebut dikarenakan keterbatasan waktu; kedua, siswa hanya sekedar menghafal teori dan persamaan tanpa memahaminya, sehingga mengakibatkan siswa 
kesulitan dalam mengerjakan soal, dan hanya menggunakan buku BSE yang kurang akan penjelasannya.

Upaya untuk meningkatkan hasil belajar siswa perlu adanya metode dan media yang relevan. Salah satu metode pembelajaran yang diasumsikan dapat meningkatkan hasil belajar siswa yaitu metode pembelajaran inkuiri terbimbing. Imas Kurniasih dan Berlin Sani (2015) berpendapat bahwa model pembelajaran inkuiri merupakan pembelajaran dengan seni merekayasa situasi-situasi yang sedemikian rupa sehingga siswa berperan sebagai ilmuwan, sedangkan Thursinawati (2012) mendefinisikan "Pembelajaran inkuiri terbimbing adalah suatu pembelajaran dengan proses penyelidikan/penemuan yang memiliki langkah-langkah kerja ilmiah untuk membentuk karakteristik saintis dan sikap ilmiah siswa dengan beranjak mempelajari konsep-konsep, fenomena dan fakta-fakta yang terjadi di jagat raya ini". Pendekatan inkuiri terbimbing digunakan bagi siswa yang kurang berpengalaman belajar dengan pendekatan inkuiri. Dengan pendekatan ini, siswa belajar lebih berorientasi kepada bimbingan dan petunjuk dari guru, sehingga ia mampu memahami konsep-konsep pelajaran.

Media yang diasumsikan dapat mendukung penerapan metode inkuiri terbimbing yaitu berupa modul. Modul ialah buku panduan yang terperinci untuk membantu siswa menemukan informasi. Pengajaran modul memberi kesempatan bagi siswa untuk belajar menurut cara masing-masing (Nasution S, 2013).

Berdasarkan uraian di atas, peneliti berupaya untuk meningkatkan hasil belajar siswa SMP dengan menerapkan metode inkuiri terbimbing berbantukan modul yang diterapkan kepada siswa kelas VIII A SMPN 1 Puhpelem semester genap tahun ajaran 2016/2017.

\section{Metode Penelitian}

Jenis penelitian yang digunakan adalah quasi eksperiment dengan desain one-group pretest postest. Populasi penelitian ini adalah kelas VIII SMPN 1 Puhpelem, dan sampel penelitiannya siswa kelas VIII A SMPN 1 Puhpelem yang berjumlah 24 siswa. Teknik pengambilan sampel dilakukan secara purposive sampling yaitu teknik pengambilan sampel berdasarkan pertimbangan tertentu, dalam penelitian ini pemilihan kelas dipertimbangkan dengan guru yang mengajar IPA di kelas tersebut.

Data yang diperoleh dalam penelitian ini adalah hasil belajar dalam ranah kognitif. Dalam penelitian ini ranah kognitif yang diukur meliputi C1 (mengingat), C2 (memahami), C3 (penerapan) dan C4 (analisis). Instrumen dalam penelitian ini yaitu Silabus, RPP, modul, dan soal pretest-postest yang telah diuji instrumen meliputi uji validitas, reliabilitas, tingkat kesukaran, dan daya pembeda. Teknik pengumpulan data yang digunakan yaitu berupa tes. Teknik tes digunakan untuk menentukan hasil belajar siswa dalam ranah kognitif. Teknik analisis data menggunakan perhitungan $\mathrm{N}-$ Gain antara nilai pretest dan postest.

\section{Hasil dan Pembahasan}

Data hasil belajar siswa terdapat dua kategori yaitu data kemampuan awal siswa diambil melalui pretest dan kemampuan akhir siswa melalui posttest. Soal-soal yang digunakan yaitu materi IPA fisika pada bab alat optik. Soal yang diujikan berbentuk pilihan ganda yang berjumlah 10 butir.

Berdasarkan penelitian yang telah dilakukan, soal yang digunakan yaitu pada kategori $\mathrm{C} 1$, C2, C3 dan C4. Pada kategori tersebut, siswa memiliki pencapaian atau penguasaan yang berbeda di setiap soalnya, yaitu sebagai berikut. 


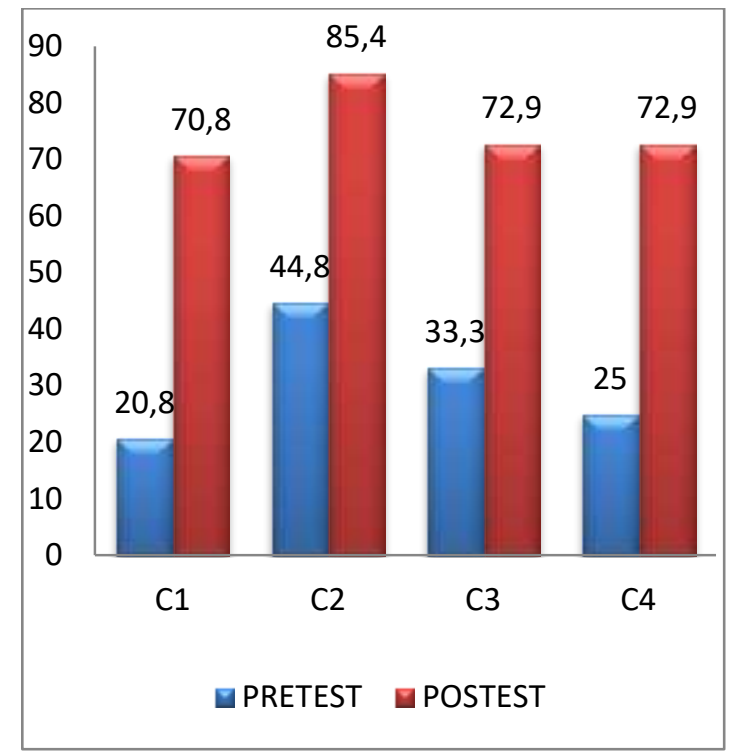

Gambar 1. Diagram penigkatan hasil belajar siswa dalam ranah kognitif

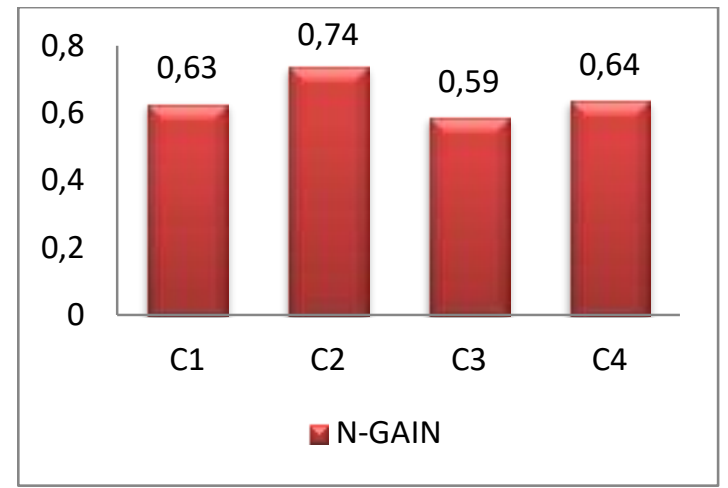

Gambar 2. Diagram N-Gain Hasil Belajar Siswa

Berdasarkan diagram 1 dan 2 dapat dilihat bahwa rata-rata nilai siswa pada ranah $\mathrm{C} 1$ (mengingat) mengalami peningkatan dari 20,8 menjadi 70,8, sedangkan $\mathrm{N}$ Gain yang diperoleh yaitu sebesar 0,63 dengan kategori sedang. Kemampuan siswa dalam mengingat dikategorikan cukup mampu, hal ini disebabkan siswa mengingat dari penjelasan-penjelasan yang terkait dengan orientasi yang disampaikan. Ranah yang mengalami peningkatan paling tinggi yaitu kategori C2 (memahami) dari 44,8 menjadi 85,4 dengan N Gain sebesar 0,74 pada kategori tinggi. Hal ini disebabkan pada tahap penerapan inkuiri terbimbing dalam percobaan siswa melakukannya sendiri terkait dengan fenomena alam sekitar yang dibantu dengan adanya modul siswa lebih mudah untuk memahami konsep fisika.

Pada ranah C3 (penerapan) nilai rata-rata siswa mengalami peningkatan dari 33,3 menjadi 72,9 dengan nilai N Gain 0,59 dalam kategori sedang. Hal ini disebabkan oleh kurangnya siswa dalam menerapkan persamaan yang terkait dengan fenomena yang dijabarkan, karena siswa belum bisa mengaitkannya. Pada ranah $\mathrm{C} 4$ (menganalisis) rata-rata siswa meningkat dari 5 menjadi 72,9 dengan $\mathrm{N}$ Gain sebesar 0,64 dengan kategori sedang.

Data deskripsi sebelum dan sesudah perlakuan dapat dilihat pada tabel 1, yaitu sebagai berikut. 
Tabel 1. Data awal dan akhir hasil belajar siswa

\begin{tabular}{lcccc}
\hline \multirow{2}{*}{ Perlakuan } & Jumlah & \multicolumn{3}{c}{ Nilai } \\
\cline { 3 - 5 } & Siswa & Maks & Min & Mean \\
\hline Sebelum & 24 & 50 & 20 & 34,17 \\
\hline Sesudah & 24 & 90 & 60 & 77,92 \\
\hline
\end{tabular}

Setelah melakukan penelitian, diperoleh hasil belajar siswa yang kemudian dilakukan uji $\mathrm{N}-$ Gain yaitu sebagai berikut.

Tabel 2. Data awal dan akhir hasil belajar siswa

\begin{tabular}{ccccl}
\hline \multirow{2}{*}{ Kelas } & Jumlah & \multicolumn{3}{c}{ Nilai } \\
\cline { 3 - 5 } & Siswa & Pre & Post & N-Gain \\
\hline Inkuiri Terbimbing & 24 & 34,17 & 77,92 & 0,67 \\
\hline
\end{tabular}

Berdasarkan data pada tabel 1 dapat dilihat bahwa rata-rata sebelum perlakuan yaitu 34,17 dan sesudah perlakuan sebesar 77,92. Dari data tersebut dilakukan uji N-Gain untuk mengetahui ada atau tidaknya peningkatan hasil belajar. N-Gain yang didapat dari kedua nilai tersebut yaitu sebesar 0,67 . Peningkatan hasil belajar ranah kognitif siswa tersebut termasuk dalam kategori sedang.

Berdasarkan hasil analisis data di atas diperoleh rata-rata pretest sebesar 34,17 dan postest sebesar 77,92. Pada tabel 2 dapat diketahui rata-rata N-Gain yaitu sebesar 0,67 dimana peningkatkan hasil belajar siswa ranah kognitif termasuk dalam kategori sedang. Dari data yang diperoleh dapat diketahui bahwa penerapan metode pembelajaran inkuiri terbimbing dengan berbantukan modul dapat meningkatkan hasil belajar siswa dalam ranah kognitif.

Metode inkuiri terbimbing yang diterapkan pada mata pelajaran fisika dapat meningkatkan hasil belajar siswa. Pada dasarnya inkuiri terbimbing mengajarkan kepada siswa untuk berlatih menyelidi suatu permasalah atau fenomena dalam kehidupan sehari-hari dan dapat memecahkannya. Dalam penerapan inkuiri terbimbing dibantu dengan penggunaan modul, dimana modul dapat membantu siswa untuk memecahkan masalah. Modul yang digunakan memiliki orientasi yang sesuai dengan lingkungan sekolah penelitian, sehingga siswa lebih mudah untuk memahaminya. Siswa lebih tertarik dengan lingkungan sekitarnya dari pada yang lain, sebab tidak semua siswa dapat menjangkau dan memikirkan kejadian yang terjadi di luar lingkungannya siswa. Hal tersebut juga dapat mempengaruhi peningkatan hasil belajar siswa.

Langkah-langkah dalam pembelajaran inkuiri terbimbing yaitu orientasi, merumuskan masalah, merumuskan hipotesis, mengumpulkan data, menguji hipotesis, merumuskan kesimpulan. Pada fase pengumpulan data siswa dipandu dengan menggunakan modul tetapi tak terlepas dari panduan guru. Aktivitas yang dilakukan akan memudahkan siswa untuk lebih memahami konsep-konsep fisika, karena siswa secara tidak langsung bisa mengaitkan fenomena yang dialami dengan materi fisika yang dipelajari. Pada penelitian ini yang diajarkan adalah materi alat optik.

Penelitian yang dilakukan oleh Novi Yuliyanti dalam Jurnal Cakrawala Pendas tahun 2016 di Universitas Majalengka dengan judul "Pengaruh Model Inkuiri Terbimbing Berbasis Lingkungan terhadap Kemampuan Pemahaman Konsep dan Karakter". Hasil penelitian menunjukkan bahwa, 1) terdapat pengaruh model pembelajaran inkuiri terbimbing berbasis lingkungan terhadap pemahaman konsep sebesar $15 \%, 2)$ terdapat pengaruh model pembelajara inkuiri terbimbing berbasis lingkungan terhadap karakter sebesar $12,2 \%, 3$ ) 
terdapat pengaruh model pembelajaran inkuiri terbimbing berbasis lingkungan terhadap pemahaman konsep dan karakter sebesar 95,2\%.

Penelitian yang dilakukan oleh Ryzal Perdana dkk dalam prossiding SNPF di Universitas Sebelas Maret yang berjudul "Pengembangan Modul Pembelajaran Kimia SMA/MA Berbasis Inkuiri Terbimbing pada Materi Pokok Hidrolis Garam". Hasil penelitian tersebut menunjukkan bahwa, 1) angket respon siswa pada uji coba luas/implementasi modul diperoleh penilaian dengan kategori "sangat baik", sedangkan angket respon guru diperoleh penilaian dengan kategori "sangat baik". Jadi modul pembelajaran kimia berbasis inkuiri terbimbing layak untuk digunakan pada proses pembelajaran. 2) ada peningkatan hasil belajar siswa setelah menggunakan modul kimia berbasis inkuiri terbimbing, hal tersebut dapat dillihat dari perbandingan skor rata-rata peningkatan hasil belajar siswa kelas eksperimen yang menggunakan modul kimia berbasis inkuiri terbimbing.

\section{Kesimpulan}

Berdasarkan penelitian yang telah dilakukan dapat disimpulkan bahwa penerapan metode pembelajaran inkuiri terbimbing berbantukan modul dapat meningkatkan hasil belajar siswa SMP dalam ranah kognitif. Hasil penelitian menunjukkan bahwa peningkatan hasil belajar tertinggi terdapat pada soal C2 (pemahaman) dengan kategori tinggi, sedangkan secara keseluruhan hasil belajar yang dilihat dari N-Gain diperoleh sebesar 0,67 , yang berarti hasil belajar siswa meningkat dalam kategori sedang.

Saran yang diberikan penulis yaitu penerapan metode inkuiri terbimbing sebaiknya dilakukan dalam jangka waktu panjang dan disesuaikan dengan materi pelajaran IPA khususnya fisika, dan berbantu media lain agar mempermudah siswa untuk memahami konsep fisika.

\section{Daftar Pustaka}

Kurniasih Imas \& Sani Berlin. 2015. Ragam Pengembangan Model Pembelajaran untuk Peningkatan Profesionalitas Guru. Jakarta: Kata Pena.

Nasution, S. 2013. Berbagai Pendekatan dalam Proses Belajar Mengajar. Jakarta: Bumi Aksara.

Perdana, Ryzal, dkk. 2016. Pengembangan Modul Pembelajaran Kima SMA/Ma Berbasis Inkuiri Terbimbing Pada Materi Pokok Hidrolis Garam. Prossiding (online), 205213.

Rahmawati. 2016. Hasil TIMSS 2015 Diagnosa Hasil untuk Perbaikan Mutu dan Peningkatan Capaian. Jakarta:

(online), (http://puspendik.kemdikbud.go.id/seminar/upload/RahmawatiSeminar\%20Hasil\%20TIMSS\%202015.pdf, diunduh 21 Agustus 2017).

Thursinawati. 2012. Penerapan Pembelajaran Inkuiri Terbimbing untuk Meningkatkan Penguasaan Konsep dan Pemahaman Hakikat Sains Siswa. Jurnal Nasional (online), 3 (1); 83-99.

Yulianti, Novi. 2016. Pengaruh Model Inkuiri Terbimbing Berbasis Lingkungan Terhadap Kemampuan Pemahaman Konsep dan Karakter. Jurnal Cakrawala Penda (online), 2 (2); 1-10. 